\title{
Abandoned landscapes - possibilities of their identification by application of map data and aerial images in conditions of Slovakia
}

\author{
Daniel Szatmári ${ }^{\mathrm{a}, *}$, Monika Kopecká ${ }^{\mathrm{a}}$, Ján Feranec ${ }^{\mathrm{a}}$, Tomáš Goga ${ }^{\mathrm{a}}$ \\ ${ }^{a}$ Institute of Geography - Slovak Academy of Sciences, daniel.szatmari@savba.sk,monika.kopecka@savba.sk, feranec@savba.sk, \\ tomas.goga@savba.sk \\ * Corresponding author
}

Keywords: Cadastre of real estate, Basic data base for the geographic information system (ZBGIS), Land Parcel Identification System (LPIS), Land Use/Cover Area frame Survey (LUCAS), Slovakia

\begin{abstract}
:
In the $20^{\text {th }}$ century the area of abandoned landscape has increased worldwide. Factors leading to landscape abandonment may include environmental (reduced soil fertility, degradation caused by overgrazing, contamination, etc.) or socio-economic causes (depopulation of the rural area in remote regions, socio-political changes, etc.). The abandoned landscape is often classified based on the physiognomic characteristics of the successional vegetation, particularly by the proportional representation of herbs, shrubs and wood species. Another way of classification is based on the time passed after the end of the last anthropogenic activity. Considering the original use of the abandoned landscapes, the post-agrarian, post-mining, post-industrial and overgrown water areas (Lipský and Kukla 2012) are discerned. The scope of abandoned landscape in Slovakia is estimated at $17.5-18.6 \%$ of farmland, i.e. $424,000-452,000$ ha (Midriak et al. 2011). The most extensive abandonment (more than 335,000 ha) is presumed in the category of grasslands. The aim of this paper is to point out the information potential of existing datasets, maps and aerial images for the identification process of the quoted four types of abandoned landscape in Slovakia.
\end{abstract}

Cadastre of real estates is both a public land register and information system containing geometrical determination, listing and description of real estate, data about the type of land parcels (land use - forest, arable land, vineyard, etc.) and the data on rights to the real estate (ownership right, mortgage right, first option, easement, rental rights connected with the state administration, communal property or those of higher territorial units). The cadastre of real estate consists of cadastral documentation arranged by cadastral districts. A cadastral map is a large-scale vector map that shows the boundaries of the cadastral districts and land parcels marked by the parcel number and the type of land parcel. Cadastre of real estate is devised to protect rights to real estate, for tax and fee purposes, evaluation of real estate, protection of the agricultural and forest pools, creation and protection of the environment, protection of mineral resources, protection of national and other cultural monuments and the protected territories and natural phenomena and also for the generation of further information systems about real estate.

The Basic data base for the geographic information system (ZBGIS) is part of the information system used by geodesy, cartography and cadastre created and administrated by the Geodesy, Cartography and Cadastre Authority of the Slovak Republic (SR). The ZBGIS is a spatial object-oriented database (available as Map client) that is the referential basis of the national infrastructure of spatial information and the basis for creating thematic geographical information systems, governmental basic and thematic maps. The purpose of the ZBGIS is the creation of the basis for relevant spatial information about the territory of the SR in a system that makes possible its storage, upgrading, analysis and displaying. ZBGIS contains data and metadata about spatial landscape objects, their spatial and thematic attributes and mutual linkages. The scope of data about objects administered by the ZBGIS is determined by the catalogue of classes of objects. One of the basic layers of the ZBGIS is the Orthophotomozaic of the SR. National Forest Centre in Zvolen and the Geodetic and Cartographic Institute in Bratislava were entrusted with its compilation. The Orthophotomosaic of the SR consists of images from 2017, 2018 and 2019 and it is upgraded in a 3-year cycle; its resolution is $25 \mathrm{~cm} /$ pixel, root mean square error is $0.30 \mathrm{~m}$.

The Land Parcel Identification System (LPIS) identifies referential parcels of agricultural areas. It is the key component of the Integrated Administration and Control System for subsidies of the European Union concerning land. LPIS represents vector borders of the agricultural landscape and bears information about the unique code, area, crop/land use, disadvantaged regions, Programme of Rural development, landscape elements, which are used as a reference for the 
applications of farmers, for administrative and cross-checking, checking in situ or by remote sensing methods. The LPIS in the SR is based on land blocks representing agricultural areas with more or less stable natural or artificial borders and one culture/land use. LPIS and its vector layer are upgraded in a 3-year cycle for the whole SR.

The Land Use/Cover Area frame Survey (LUCAS) is a harmonized in situ land cover/land use (LC/LU) data, agroenvironmental and soil data collection/monitoring coordinated by the Eurostat. The result of the campaign is a dataset serving as a base for creating indicators of sustainable development. Microdata of the survey and the database of photodocumentation then represent a component of referential data of the Copernicus system; LC/LU statistics serve as a support for the harmonization of the data of the European Union Member States. The national coordinator is the National Agriculture and Food Centre - Soil Science and Conservation Research Institute. The classifications used within LUCAS are comparable with other statistical standards, for example, standards used in the European Union's farm structure survey, those used by the United Nations' Food and Agriculture Organisation, or the European Nature Information System for classifying forestry types and areas. The classification of LC/LU consists of 8 categories, 29 classes and 4 categories, 16 classes, respectively.

Identification of the abandoned landscape was based on the principles of retrospective analysis, i.e. backdating (Feranec et al. 2005): the result of overlapping layers of LU, that is, referential (e.g., year 2000) and the topical (year 2020). Changes in the shape and content of landscape areas in topical layer versus referential layer presented the signs of abandonment and its enlargement or diminishment (Fig. 1). The obtained results document the occurrence of four types of abandoned landscape identified in Slovakia.

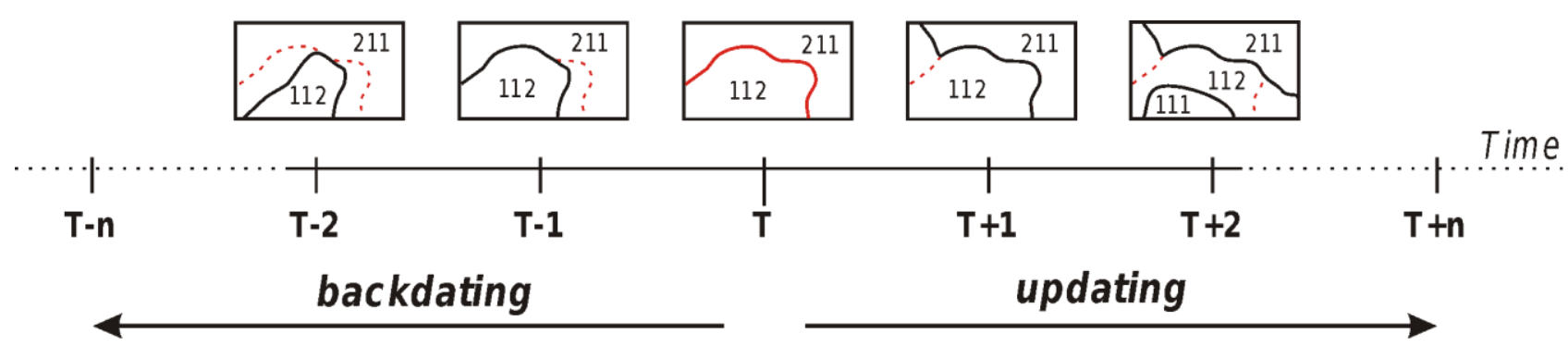

Figure 1. Basic principles of backdating and updating: $\mathrm{T}$ is the referential layer in time " $\mathrm{t}$ ", $\mathrm{T}-1$ to $\mathrm{T}-\mathrm{n}$ reconstructed past states and $\mathrm{T}+1$ to $\mathrm{T}+\mathrm{n}$ are generated new states of $\mathrm{LC} / \mathrm{LU}$ classes in the corresponding time horizons.

\section{Acknowledgements}

This work was supported by the Slovak Scientific Grant Agency VEGA under Grant 2/0023/19, "Land cover dynamics as indicator of changes in landscape".

\section{References}

Feranec, J., Cebecauer, T. and Ot'ahel', J., 2005. Photo-to-photo interpretation manual. Institute of Geography, Slovak Academy of Sciences, Bratislava, BIOPRESS document, biopress-d-13-1.3.

Lipský, Z. and Kukla, P., 2012. Mapping and typology of unused lands in the territory of the town Kutná Hora (Czech Republic). In: AUC Geographica, Vol. 47, No. 1, pp. 65-71, doi: 10.14712/23361980.2015.25.

Midriak, R., Zaušková, L., Sabo, P., Gallay, I., Gallayová, Z., Lepeška, T., Hladká, D., Lipták, J., Šály, R., Krajčovič, V., Eliáš, P., Šebeň, V., Šmelko, Š., Turisová, I., Uhliarová, E., Švidroň, I. and Cochová, S., 2011. Spustnuté pôdy a pustnutie krajiny Slovenska [Waste lands and the abandoning landscape of Slovakia]. Banská Bystrica: Univerzita Mateja Bela, ISBN 978-80-557-0110-3. (in Slovak with English summary) 